\title{
Government Sukuk and Sharia Mutual Funds to The Investment Yield Sharia Insurance in Indonesia
}

\author{
Mohd. Heikal ${ }^{1}$, Iskandar Muda ${ }^{2}$, Muammar Khaddafi ${ }^{1}$, Wahyuddin ${ }^{1}$ and Damanhur ${ }^{1}$ \\ \{mohdheikal@unimal.ac.id, iskandar1@usu.ac.id,khaddafi@unimal.ac.id\} \\ ${ }^{1}$ Faculty of Economics, Universitas Malikussaleh, Lhokseumawe, Indonesia \\ ${ }^{2}$ Faculty of Economics and Business, Universitas Sumatera Utara, Medan, Indonesia
}

\begin{abstract}
This study aims to analyzed the effect of Government Sukuk and Sharia Mutual Funds to The Investment Yield Sharia Insurance in Indonesia. The data sourced from Financial Services Authority (OJK) Indonesia and using Smart PLS software to analysis. The method of research using a causal research design in Indonesia Sharia Insurance. The Government Sukuk and Sharia Mutual Funds influence to Investment Yield Sharia Insurance in Indonesia. The limitations of the study used a 2-year sample and only 2 variables and the results of this study have implications for Indonesia's Financial Services Authority (OJK) in formulating Sharia insurance policy in Indonesia. New findings related to Government Sukuk impacting the sharia insurance industry in Indonesia.
\end{abstract}

Keywords: Investment Yield, Government Sukuk, Sharia Mutual Funds

\section{Introduction}

The Retail State Sukuk is a Government Securities issued based on sharia principles designated for individual investors of citizens [1], (Zaman, 1993; Warde, 2000). Retail State Sukuks are issued in scripless form, but to investors will be given Proof of Ownership Letter. In Act Legal no. 19 of 2008 it is state that underlying assets are SBSN assets. The SBSN assets are objects and/or state property which have economic value, in the form of land and/or building, which in the framework of issuance of SBSN serve as the basis for SBSN issuance. As for the meaning of state property is all goods purchased or obtained at the expense of state budget revenue or derived from other legitimate acquisition. The main objective of the government to issue sukuk is sources of financing to the construction of the project. As mentioned in Article 4 of the SBSN Law, the purpose of SBSN is to finance the State Revenues and Expenditures Budget, including to finance the project development. Projects that can be financed by state sukuk are the manufacturing and housing sectors. One of the supporting factors in sustainable economic development is the availability of adequate infrastructure (Kia, 2013; Tabash, 2014). To build adequate infrastructure, the government uses a source of state financing where almost every year APBN deficit. Although foreign debt has a positive impact. However, in the long term foreign debt influence to confition of the state. In this case Sukuk Ritel is present as an alternative solution of Infrastructure financing Indonesia. Retail State Sukuk is a State Sharia Securities sold to individuals through a Selling Agent, at a specified minimum volume. All Indonesian citizens can invest in Retail State Sukuk. This Sukuk issuance uses Ijarah contract with Underlying asset used in projects of State Revenue and Expenditure Budget and State Property. 


\section{Methodology}

This is analyzing causality between variables. While in the exprimental research, the researcher creates a "cause" by deliberately making a group difference and then observing the different effects on several dependent variables (Sirojuzilam and Muda, 2016; Tarmizi, Daulay and Muda., 2016; Dalimunthe, Fadli and Muda, 2016; I. Muda et al., 2016; Iskandar Muda, Sihombing, et al., 2016; Saputra and Muda, 2017; Azlina et al., 2017; Badaruddin et al., 2017; Nurlina and Muda, 2017; Sirojuzilam and Muda, 2017; Sihombing et al., 2017; Dalimunthe and Muda, 2017; Erlina, Tarigan and Muda, 2017; Ferine, Ermiaty and Muda, 2017; Muda, Rahmanta and Marhayanie, 2017; Muda, Rahmanta, et al., 2018; Muda, Siregar, et al., 2018; Muda and Hutapea, 2018). The simplest distinction between an exprimental study and a comparative causal study is that in an exprimental study of independent variables, in comparative causal studies it does not, it has appeared earlier. So comparative research is a type of research compare groups of a particular variable. Data obtained at the Financial Services Authority from Januari 2015-September 2017.

\section{Result And Discussion}

\subsection{Result}

The percentage variance described in Inner model. The independent variables tested have an effect significantly to the dependent variable. The coefficient result 0.005 value $<5 \%$ the decision is reject $\mathrm{H}_{0}$ and the hypothesis Ha accepted (Muda and Naibaho, 126AD; Iskandar Muda, Panjaitan, et al., 2016; Nasir, Basri and Muda, 2017; Sadalia, Rahamani and Muda, 2017; Situmorang, Rini and Muda, 2017; Yahya, Torong and Muda, 2017; Muda and Nurlina, 2018; Muda, Harahap, et al., 2018; Muda, Roosmawati, et al., 2018; Pohan et al., 2018). The result of $t$-statistics value in the Table $1 \&$ Figure 1 :

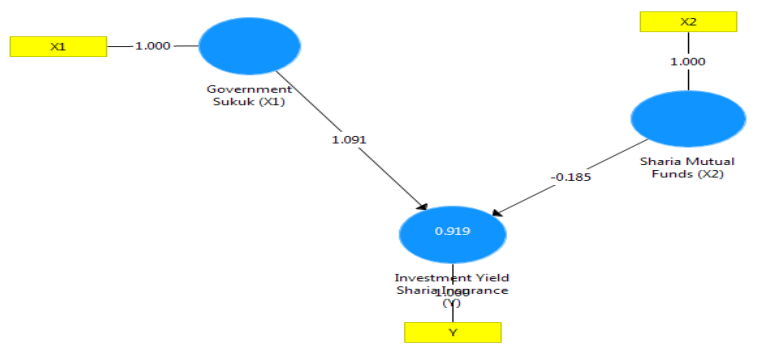

Fig. 1. Overall Model with Coefecient

The effect test as follows :

Table 1. The result of Bootsraping

\begin{tabular}{llll}
\hline & \multirow{2}{*}{ Mean } & $t$ & $p$ \\
& Statistics & Values \\
\hline Government Sukuk & 0,932 & 2,582 & 0,010 \\
(X1) $>$ Investment & & & \\
Yield Sharia & & & \\
Insurance (Y) & & & \\
\hline Sharia Mutual & & 0,422 & 0,673 \\
Funds (X2) -> & 0,019 & & \\
Investment Yield & & & \\
\hline
\end{tabular}




\begin{tabular}{ll}
\hline $\begin{array}{l}\text { Sharia } \\
\text { (Y) }\end{array}$ & Insurance \\
\hline
\end{tabular}

The Government Sukuk are significant variables on Investment Yield. In addition to hypothesis testing through the bootsrapping menu that produces $t$-statistics, inner model evaluation is also done by reviewing the R-Square value (Muda and Dharsuky, 2015; Gusnardi and Muda, 2016; Lubis, Lubis and Muda, 2016; Lubis, Torong and Muda, 2016; Lutfi, Nazwar and Muda, 2016; Handoko and Muda, 2017; Hasan, Gusnardi and Muda, 2017; Hutagalung et al., 2017; Marhayanie and Muda, 2017; Muda and Hasibuan, 2018; Khaddafi et $a l ., 2018)$. The R-square value generated from the inner model evaluation is :

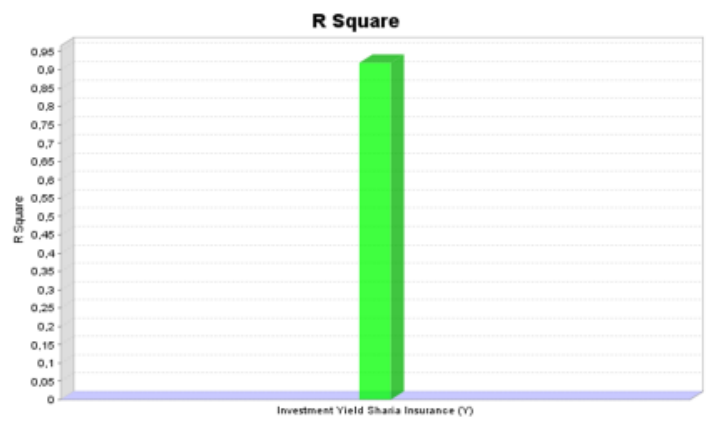

Fig. 2. F Square

\begin{tabular}{lll}
\multicolumn{4}{c}{ Table 2. R-Square Value } \\
\hline \multicolumn{4}{r}{$\begin{array}{l}\mathrm{R} \\
\text { Square }\end{array}$} & $\begin{array}{l}\mathrm{R} \\
\text { Adjusted }\end{array}$ \\
\hline $\begin{array}{l}\text { Investment } \\
\begin{array}{l}\text { Sharia } \\
\text { (Y) Insurance }\end{array}\end{array}$ & 0,919 & 0,910 \\
\hline
\end{tabular}

The variation of R-Square value of $91.9 \%$. The existence of give contribution on Investment Yield Sharia Insurance.

\subsection{Discussion}

As one of sharia sukuk have different characteristics with bonds. Sukuk must have assets underlying asset. The sukuk funds should be used for halal business activities. The Sukuk give profit sharing or margin. Islamic economics is an economics values or teachings. Secondly, what is meant by Islamic economics is as a system (Siddiqi, 1996; Ahmed, 2004; Shakespeare, 2006; Chapra, 2008; Čihák and Hesse, 2008; Osservatore, 2009; Shanmugam, 2009). The system concerning the regulation is the regulation of economic activity in a society or country based on a certain way or method. Islamic economics in terms of Islamic economies. These three areas, namely the theory, activities and economic system of Muslims are the three pillars that must form a synergy. Islam is not merely a belief, but a many aspects (Suprianto et al., 2017; Farag, Mallin and Ow-Yong, 2018). Islamic teachings include about the ideal concept in social, economic, and political aspects. The ideal concept is listed complete in Islamic law called sharia. Sharia rules have a way of solving all life problems. 
The main concept of Islamic economy is balance. All principles in the Islamic finance industry have the goal of providing prosperity to the people. A Balance between Physical and Spiritual Needs. Islam strongly encourages its people to give priority to worship more than anything else (Kia, 2013). Not that Muslims are forbidden to do activities outside of it. Livelihood activities must be balanced with worship activities. The rules of Islam establish economic activity in sharia forming. Muslims are obliged to obey the provisions of sharia in many aspect. The reply to Muslim obedience is the reward and the smoothness of seeking sustenance on earth. Every the goal of creating justice for all beings in the world.

\subsection{Limitation and implications}

The limitations of the study used a 2-year sample and only 2 variables and the results of this study have implications for Indonesia's Financial Services Authority (OJK) in formulating Sharia insurance policy in Indonesia.

\section{Conclusions}

The Government Sukuk and Sharia Mutual Funds influence to Investment Yield Sharia Insurance in Indonesia

\section{References}

[1] Ahmed, A. (2004) Role of Zakah and Awqaf in Poverty Alleviation, Islamic Development Bank Group Islamic Research and Training Institute. doi: http://dx.doi.org/10.1016/j.biortech.2015.03.111.

[2] Azlina, N., Hasan, A., Desmiyawati and Muda, I. (2017) 'The effectiveness of village fund management (case study at villages in coastal areas in Riau)', International Journal of Economic Research, 14(12), pp. 325-336. doi: 10.1111/ele.12484.

[3] Badaruddin, B., Revida, E., Ermansyah, E. and Muda, I. (2017) 'Village governance with implementation of law number 6 of 2014 on the village and village administration', International Journal of Economic Research, 14(17), pp. 389-402.

[4] Chapra, M. U. (2008) 'The Global Financial Crisis: Can Islamic Finance Help Minimize the Severity and Frequency of Such a Crisis in the Future?', in Forum on the Global Financial Crisis. Islamic Development Bank.

[5] Čihák, M. and Hesse, H. (2008) Islamic Banks and Financial Stability: An Empirical Analysis. WP/08/16. doi: 10.1080/09540121.2015.1120266.

[6] Dalimunthe, D. M. J. far, Fadli, F. and Muda, I. (2016) 'The application of performance measurement system model using Malcolm Baldrige Model (MBM) to support Civil State Apparatus Law (ASN) number 5 of 2014 in Indonesia', International Journal of Applied Business and Economic Research, 14(11), pp. 73977407.

[7] Dalimunthe, D. M. J. and Muda, I. (2017) 'The Empirical Effect of Education and Training to The Performance of Employees', International Journal of Economic Research, 14(21), pp. 403-413.

[8] Erlina, Tarigan, Z. A. and Muda, I. (2017) 'Antecedents of budget quality empirical evidence from provincial government in Indonesia', International Journal of Economic Research, 14(12), pp. 301-312.

[9] Farag, H., Mallin, C. and Ow-Yong, K. (2018) 'Corporate governance in Islamic 
banks: New insights for dual board structure and agency relationships', Journal of International Financial Markets, Institutions and Money, 54, pp. 59-77. doi: 10.1016/j.intfin.2017.08.002.

[10] Ferine, K. F., Ermiaty, C. and Muda, I. (2017) 'The Impact of Entrepreneurship and Competence On Small Medium Enterprises Tangan Di Atas Medan Entrepreneurs' Work Performance', International Journal of Economic Research., 14(6), pp. 380-393.

[11] Gusnardi, R. R. and Muda, I. (2016) 'Competency mapping and analysis of students competency based on economics subject national examination and its alternative solutions in state high schools at Pekanbaru.', International Journal of Economic Research, 3(5), p. 2133-2148.

[12] Handoko, B. and Muda, I. (2017) 'Difference Analysis of Consumer Perception of Motorcycle Product Quality', International Journal of Economic Research, 14(14), pp. 363-379.

[13] Hasan, A., Gusnardi and Muda, I. (2017) 'Analysis of taxpayers and understanding awareness increase in compliance with taxpayers individual taxpayers', International Journal of Economic Research, 14(12), pp. 75-90.

[14] Hutagalung, B., Dalimunthe, D. M. ., Pambudi, R., Hutagalung, A. Q. and Muda, I. (2017) 'The Effect of Enterpreneurship Education and Family Environment Towards Students' Entrepreneurial Motivation', International Journal of Economic Research, 14(20), pp. 331-348.

[15] Khaddafi, M., Wahyuddin, Heikal, M., Falahuddin and Maulida, R. (2018) 'Effect of corporate governance mechanism, independence and management of earnings integrity of financial statements (In manufacturing companies listed on the stock exchange)', Quality - Access to Success, 19(164), pp. 94-97.

[16] Kia, A. (2013) Islam and the Stock Market in Islam and the economy. Edited by M. K. Hassan and M. K. Lewis. Oxford: Oxford University Press.

[17] Lubis, A. F., Lubis, T. A. and Muda, I. (2016) 'The role of Enterprise Resource Plan (ERP) configuration to the timeliness of the financial statement presentation', International Journal of Applied Business and Economic Research, 14(11), pp. 75917608.

[18] Lubis, A., Torong, Z. B. and Muda, I. (2016) 'The urgency of implementing balanced scorecard system on local government in North Sumatra - Indonesia', International Journal of Applied Business and Economic Research, 14(11), pp. 7575-7590.

[19] Lutfi, M., Nazwar, C. and Muda, I. (2016) 'Effects of investment opportunity set, company size and real activity manipulation of issuers in Indonesia Stock Exchange on stock price in Indonesia', ". International Journal of Economic Research, 13(5), pp. 2149-2161.

[20] Marhayanie, M. I. and Muda, I. (2017) 'Impact of The Online Car Rental Service Order System on Sales Turnover with Financial Literacy Customer as Intervening Variables', International Journal of Economic Research, 14(21), pp. 317-332.

[21] Muda, I. and Dharsuky, A. (2015) 'Impact of Region Financial Information System (SIKD) Quality, Role Ambiguity and Training on Precision of Financial Statement of Local Government Presentation In North Sumatra', International Journal of Applied Business and Economic Research, 13(6), pp. 4283-4304.

[22] Muda, I., Dharsuky, A., Sadalia, I. and Siregar, H. . (2016) 'Impact of capital investments and cash dividend policy on Regional Development Bank PT. Bank Sumut to the district own source revenue and economic growth', International Journal of Applied Business and Economic Research, 14(11), pp. 7863-7880. 
[23] Muda, I., Harahap, A. H., Erlina, Ginting, S., Maksum, A. and Abubakar, E. (2018) 'Factors of quality of financial report of local government in Indonesia', in $i O P$ Conference Series: Earth and Environmental Science PAPER, pp. 1-7. doi: $10.1088 / 1755-1315 /$.

[24] Muda, I. and Hasibuan, A. N. (2018) 'Public Discovery of the Concept of Time Value of Money with Economic Value of Time', in Proceedings of MICoMS 2017. Emerald Group Publishing Limited, pp. 251-257. doi: 10.1108/978-1-78756-793-1-00050.

[25] Muda, I. and Hutapea, A. A. F. (2018) 'Influence of capital expenditure and income original region to the income per capita in Indonesia', IOP Conference Series: Earth and Environmental Science PAPER, 126, pp. 1-7. doi: 10.1088/1755-1315/.

[26] Muda, I. and Naibaho, R. (126AD) 'Variables influencing allocation of capital expenditure in Indonesia', in IOP Conference Series: Earth and Environmental Science PAPER, pp. 1-9. doi: 10.1088/1755-1315/.

[27] Muda, I. and Nurlina, N. (2018) 'Influence of Manufacture of Textiles, Clothing, and Leather and Manufacture of Paper, Printing, and Publishing on Economic Growth', in Emerald Reach Proceedings Series. EmeraldPublishingLimited, pp. 107-113. doi: 10.1108/978-1-78756-793-1-00048.

[28] Muda, I., Panjaitan, R., Erlina, E., Ginting, S., Maksum, A. and Abubakar, A. (2016) 'Model application of Murabahah financing acknowledgement statement of Sharia accounting standard No 59 Year 2002', IOP Conference Series: Earth and Environmental Science, 41(12), pp. 331-335. doi: 10.1088/1755-1315/.

[29] Muda, I., Rahmanta, Marhayanie and Putra, A. S. (2018) 'Institutional Fishermen Economic Development Models and Banking Support in the Development of the Innovation System of Fisheries and Marine Area in North Sumatera', IOP Conference Series: Materials Science and Engineering, 288(1), pp. 1-7. doi: 10.1088/1757899X/288/1/012082.

[30] Muda, I., Rahmanta, S. A. and Marhayanie, M. (2017) 'The Role of Working Capital, Productivity, Applied Technology and Selling Market Prices on Fisherman's Revenues', International Journal of Economic Research, 14(20), pp. 85-97.

[31] Muda, I., Roosmawati, F., Siregar, H. S., Ramli, Manurung, H. and Banuas, T. (2018) 'Performance Measurement Analysis of Palm Cooperative Cooperation with Using Balanced Scorecard', IOP Conference Series: Materials Science and Engineering, 288(1). doi: 10.1088/1757-899X/288/1/012081.

[32] Muda, I., Sihombing, M., Jumilawati, E. and Dharsuky, A. (2016) 'Critical success factors downstream palm oil based Small and Medium Enterprises (Sme) in Indonesia', International Journal of Economic Research, 13(8), pp. 3531-3538.

[33] Muda, I., Siregar, H. S., Sembiring, S. A., Ramli, Manurung, H. and Zein, Z. (2018) 'Economic Value of Palm Plantation in North Sumatera and Contribution to Product Domestic Regional Bruto', IOP Conference Series: Materials Science and Engineering, 288(1). doi: 10.1088/1757-899X/288/1/012080.

[34] Nasir, A., Basri, Y. M. and Muda, I. (2017) 'Effectiveness of Potential Tax Region as the Real Local Revenue Sources in Riau Coastal Area', International Journal of Economic Research, 14(2), pp. 313-324.

[35] Nurlina, N. and Muda, I. (2017) 'The Analysis of The Effects of Capital Expenditure and Human Development Index on Economic Growth and Poverty in East Aceh Regency', International Journal of Economic Research, 14(16), pp. 395-409.

[36] Osservatore, V. (2009) 'Islamic Banking May Help Overcome Crisi', Press Release.

[37] Pohan, N., Badaruddin, Dalimunthe, R. F., Purwoko, A. and Muda, I. (2018) 'The 
effects of human resource development and institutional arrangements on performance, service quality and area development in indonesia', Quality - Access to Success, 19(163), pp. 94-103.

[38] Sadalia, I., Rahamani, N. A. B. and Muda, I. (2017) 'The significance of internet based financial information disclosure on corporates' shares in Indonesia', International Journal of Economic Research, 14(12), pp. 337-346.

[39] Saputra, E. A. and Muda, I. (2017) 'The Analysis of the Influencing Factors of Budget Absorption', International Journal of Economic Research, 14(12), pp. 287-300.

[40] Shakespeare, R. (2006) An Islamic Money Supply as the Means to Integration. 7HUFIslamicFinance-rs-0603. Havard.

[41] Shanmugam, B. (2009) A Primer on Islamic Finance. 1st editio. Lois Carrier.

[42] Siddiqi, M. N. (1996) Role of Fiscal Policy in Controlling Inflation in Islamic Framework, S. Available at: http://www.siddiqi.com/mns/FiscalPolicy.html (Accessed: 11 January 2019).

[43] Sihombing, M., Muda, I., Jumilawati, E. and Dharsuky, A. (2017) 'Factors Affecting The Success of Local Innovation Systems with Government Programs As Moderators', International Journal of Economic Research, 14(21), pp. 272-289.

[44] Sirojuzilam, H. and Muda, I. (2016) 'Identification of factors of failure of Barisan Mountains Agropolitan area development', International Journal of Economic Research, 13(5), pp. 2163-2175.

[45] Sirojuzilam, H. and Muda, I. (2017) 'Effect of Private Collaborative as a Moderation of Success of Agropolitan', International Journal of Economic Research, 14(20), pp. $463-475$.

[46] Situmorang, S. H., Rini, E. S. and Muda, I. (2017) 'Customer Experience, Net Emotional Value and Net Promoter Score on muslim middle class women in Medan', International Journal of Economic Research, 14(20), pp. 269-283.

[47] Suprianto, E., Suwarno, S., Murtini, H., Rahmawati, R. and Sawitri, D. (2017) 'Audit Committee Accounting Expert and Earnings Management with "Status" Audit Committee as Moderating Variable', Indonesian Journal of Sustainability Accounting and Management, 1(2), p. 49. doi: 10.28992/ijsam.v1i2.16.

[48] Tabash, M. I. (2014) 'The Relevance of Islamic Finance Principles in Economic Growth', International Journal of Emerging Research in Management \&Technology, 9359(2), pp. 49-54. Available at: http://www.ermt.net.

[49] Tarmizi, H. B., Daulay, M. and Muda., I. (2016) 'The influence of population growth, economic growth and construction cost index on the local revenue of tax on acquisition of land and building after the implementation of law no. 28 of 2009', International Journal of Economic Research, 13(5), pp. 2285-2295.

[50] Warde, I. (2000) Islamic finance in the global economy. Edinburgh: Edinburgh University Press.

[51] Yahya, I., Torong, M. Z. B. and Muda, I. (2017) 'Influence behavior in legislature budget development of regions in the province of aceh and North Sumatra', International Journal of Economic Research, 14(8), pp. 147-156.

[52] Zaman, S. M. H. (1993) 'Indexation of Financial Assets: An Islamic Evaluation', $J$. Res. Islamic Econ, 2(2), pp. 31-49. doi: 10.1007/BF00810591. 